\begin{tabular}{l|c|c}
\hline ISSN: 0001-5113 & ACTA ADRIAT., & ORIGINAL SCIENTIFIC PAPER \\
AADRAY & $60(1): 69-78,2019$ & \\
\hline
\end{tabular}

\title{
The influence of feeding on muscle tissues composition in cage reared bluefin tuna (Thunnus thynnus)
}

\author{
Ivana MILETIĆ ${ }^{1}$, Ivona MLADINEO², Stjepan ORHANOVIĆ ${ }^{3}$, \\ Maja PAVELA-VRANČIĆ ${ }^{3}$, Merica SLIŠKOVIĆ ${ }^{4 *}$, Gorana JELIĆ MRČELIĆ ${ }^{4}$ \\ ${ }^{1}$ Permanent Representation of Croatia to the European Union, \\ Avenue des Arts 50, 1000 Bruxelles, Belgium \\ ${ }^{2}$ Institute of Oceanography and Fisheries, \\ Šetalište I. Mestrovića 63, P.O. Box 500, 21000 Split, Croatia \\ ${ }^{3}$ University of Split, Faculty of Science, Ruđera Boškovića 33, 21000 Split, Croatia \\ ${ }^{4}$ University of Split, Faculty of Maritime Studies, Ruđera Boškovića 37, 21000 Split, Croatia \\ *Corresponding author e-mail: merica@pfst.hr
}

Capture-based tuna aquaculture rates as one of the most important aquaculture activities in Croatia, where juvenile tuna are reared in cages for over a year long period in order to increase substantially their weight. The aim of this study was to assess the effect of length and intensity of feeding on biochemical composition (total fat, moisture, dry matter, carbohydrates and protein content) of tuna (Thunnus thynnus) white muscle tissues in newly caught tuna prior to feeding (NCTPF) versus farmed tuna kept in rearing circular cages in the Vela Grska Bay, Adriatic Sea (LAT 4317'40,6984'N, $L O N G 016^{\circ} 28^{\prime} 58,4315^{\prime \prime} E$ (WGS84)) between 2001 and 2004. Farmed tunas from all cages were fed with the feed consisting of domestic small pelagic fish, or with mixtures containing North Sea herring (Clupea harengus) and Sardina pilchardus, for five months (cage 3), eight months (cage 4) or 21 months (cages 1 and 2). A low content of moisture and high content of dry matter including fat was observed in farmed tuna muscles compared to wild-caught tuna. In farmed tuna muscles, measured moisture was $55.26 \%$ in cage 1, 39.95\% in cage 2, 54.64\% in cage 3 and $49.70 \%$ in cage 4. These results are significantly lower than moisture measured in NCTPF (80.36\%). Content of dry matter found in farmed tuna muscles also differed greatly between wild tuna (19.64\%) and farmed tuna, but also between the cages (44.74\% in cage 1, 60.05\% in cage 2, 45.36\% in cage 3 and $50.30 \%$ in cage 4). In NCTPF, muscle tissues total fat encompassed less than $1 \%$ of the total body weight, while it reached over $20 \%$ of total body mass in farmed fed tuna $(20.62 \%$ in cage $1,42.50 \%$ in cage 2, 20.97\% in cage 3 and $20.57 \%$ in cage 4). These results demonstrate that high fat content can be achieved already after five months of intensive feeding. Higher content of proteins was also found in aquacultured tuna (18.60\% in cage 1, 16.00\% in cage 2, 15.09\% in cage 3 and 20.58\% in cage 4) compared to wild-caught tuna (13.77\%). There were no differences in carbohydrates content between tuna farmed in different cages and NCTPF tuna, indicating glycogen as a less optimal indicator of muscle tissue quality in farmed tuna of the present study.

Key words: bluefin tuna, feeding, muscle tissue composition, cage rearing, the Grška Bay 


\section{INTRODUCTION}

Since the first attempts of tuna (Thunnus thyn$n u s$ ) capture-based aquaculture, its fattening and rearing technology has continued to develop, as the species continued to have a global economic importance based on the high market demand and high price, mostly due to the desirable biochemical composition of its meat (BIMOL et al., 2010). In the late 1960s, Japan started the first tuna rearing activities in Canadian waters by keeping fish in cages for several months. Fish gained in mass and fat content during the feeding period, so that even medium size tuna could be sold in the Japanese market for a relatively good price, providing it had a high fat content and pink meat color. In 1996, fishermen returning to Croatia from Australia, started tuna rearing by applying their Australian experience (KATAVIĆ et al., 2003). Since then, the production sharply increased, resulting in 2,162 tons produced in 2017, with the ICCAT (International Commission for the Conservation of Atlantic Tunas) quota set at 779.84 tons for 2018 (GRUBIŠIĆ, personal communication). However, the difference in Mediterranean and Croatian tuna aquaculture is that in the former, adult tuna over $30 \mathrm{~kg}$ are caught therefore the fattening period lasts for six to ten months, in contrast to Croatia, where mostly juvenile tuna of 8 to $12 \mathrm{~kg}$ are caught and the rearing period lasts 1.5 years or more.

Although having a relatively long capture-based aquaculture history, according to MOURENTE \& TOCHER (2009) little is known about the quantitative or qualitative nutritional requirements of large Thunnini. The body composition of wild tuna may indicate possible dietary requirements, at least in respect to the fat content and fatty acid composition. Therefore, the investigation of the feeding effect on the biochemical composition of farmed fish has lately been intensified. SORIGUER et al. (1997) observed significant variations in the total fat, protein and fatty acid content in baitfish used for tuna feeding. GLENCROSS et al. (2007) highlighted that the evaluation of feed ingredients is crucial to nutritional research and feed development for aquaculture species. Likewise, MLADINEO et al. (2006) reported a devastating outbreak of pasteurelosis in farmed tuna, related to long-term misbalanced feeding with poor-quality baitfish. Furthermore, the fact that meat fat levels can vary so widely has important consequences for farming. Generally, consumers assume that farmed fish are poor in quality and flavor compared to their wild counterparts (HAARD, 1992; RASMUSSEN, 2001; TOMIĆ et al., 2017). Indeed, some authors suggest (FARNDALE et al., 1999; HEMRE \& SANDNES, 1999; SKOG et al., 2003) that wild fish tend to be leaner and firmer than the latter, attributing this to a high fat content in cultured fish (RASMUSSEN, 2001; FLOS et al., 2002; GRIGORAKIS et al., 2002). Differences between wild fish and their cultured counterparts have been observed in a variety of fish species (GRIGORAKIS et al., 2002; ORBAN et al., 2003), but unlike in other cultured fish, high fat content in aquaculture tuna is highly prized in the sushi and sashimi Japanese market, although its quantitative and qualitative profiles are not always the only reliable indicators of fish value. The aim of this study was to assess the effect of length and intensity of feeding on the biochemical composition (total fat, moisture, dry matter, carbohydrates and protein content) of tuna white muscle tissues in wild non-fed tuna and aquacultured tuna kept in rearing circular cages in the Grška Bay (LAT 4317’40,6984”N, LONG $016^{\circ} 28^{\prime} 58,4315^{\prime \prime} \mathrm{E}$ (WGS84)) between 2001 and 2004.

\section{MATERIAL AND METHODS}

\section{Experimental design}

Tuna (Thunnus thynnus) was farmed in four circular cages $(60 \mathrm{~m}$ in diameter and 25 $m$ deep) in the Grška Bay, Adriatic Sea (LAT

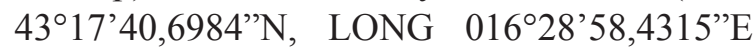
(WGS84)) from summer 2001 till winter 2004. Tuna had been caught SW of the Island of Jabu$\mathrm{ka}$, the Adriatic Sea, using purse seine nets. Wild caught individuals differed in biomass (Table 1).

During the farming period, sea temperature $\left({ }^{\circ} \mathrm{C}\right)$ and oxygen saturation (\%) were measured at the sea surface and at $15 \mathrm{~m}$ depth, three times a day, every day. The measurements were 
MiLETIĆ et. al.: The influence of feeding on muscle tissues composition in cage reared bluefin tuna ...

Table 1. The weight categories $(\mathrm{kg})$ and number of individuals, total weight $(\mathrm{kg})$ and density $\left(\mathrm{kg} / \mathrm{m}^{3}\right)$ of tuna in the cages at the beginning and at the end of feeding process

\begin{tabular}{|c|c|c|c|c|c|c|c|c|}
\hline \multirow[t]{3}{*}{ CAGE } & \multicolumn{7}{|c|}{ REARED TUNA } & \multirow[b]{3}{*}{$\begin{array}{l}\text { Density } \\
\left(\mathrm{kg} / \mathrm{m}^{3}\right)\end{array}$} \\
\hline & \multicolumn{3}{|c|}{$\begin{array}{c}\text { At the beginning of the feeding } \\
\text { process }\end{array}$} & \multicolumn{4}{|c|}{ At the end of the feeding process } & \\
\hline & $\begin{array}{l}\text { Weight } \\
\text { categories } \\
\text { of indiv. } \\
(\mathrm{kg})\end{array}$ & $\begin{array}{l}\text { No. of } \\
\text { indiv. }\end{array}$ & $\begin{array}{l}\text { Total } \\
\text { mass } \\
(\mathrm{kg})\end{array}$ & $\begin{array}{l}\text { Density } \\
\left(\mathrm{kg} / \mathrm{m}^{3}\right)\end{array}$ & $\begin{array}{c}\text { Weight } \\
\text { categories } \\
(\mathrm{kg})\end{array}$ & $\begin{array}{l}\text { No. of } \\
\text { indiv. }\end{array}$ & Total weight $(\mathrm{kg})$ & \\
\hline 1 & 3.5 & 7183 & 25919 & 0.73 & 27 & 5314 & 142404 & 4.03 \\
\hline 2 & 3.5 & 6743 & 23562 & 0.36 & 27 & 3236 & 110913 & 1.72 \\
\hline \multirow{4}{*}{3} & 11.0 & 713 & 7854 & & 29 & 265 & 7641 & \\
\hline & 17.0 & 265 & 4505 & & 31 & 671 & 20801 & \\
\hline & 30.0 & 524 & 15720 & & 56.5 & 514 & 29052 & \\
\hline & total & 1502 & 28079 & 1.06 & & 1450 & 57494 & 2.04 \\
\hline \multirow{3}{*}{4} & 11.0 & 5137 & 56507 & & 27 & 4964 & 133457 & \\
\hline & 20.0 & 80 & 1600 & & 51 & 77 & 3940 & \\
\hline & total & 5217 & 58107 & 1.41 & & 5041 & 137398 & 3.33 \\
\hline
\end{tabular}

made between 07:00 and 08:00 in the morning, between 13:00 and 14:00 in the afternoon and between 18:00 and 19:00 in the evening, using Sinergia WTR portable oximeter.

Tuna was fed with domestic small pelagic fish (DSPF - pilchard (Sardina pilchardus), anchovy (Engraulis encrasicolus) and mackerel (Scomber scombrus) depending on seasonal availability, and a mixture of imported herrings (Clupea harengus) and pilchard (Sardina pilchardus) from the North Sea. Herring and pilchard were kept in frozen blocks $(30 \mathrm{~kg})$ at $-20{ }^{\circ} \mathrm{C}$ and defrosted in a defrosting plant using sea water. Defrosted fish were kept in plastic containers $(800$ $\mathrm{kg}$ ) and transported to the vessels for feeding.

In cage 1, the tuna formed weight category (NFTPF) $3.5 \mathrm{~kg}$ and tuna were farmed for 21 months (552 days; from May 2001 till January 2003). Cage 1 was located in the Mala Maslinova Bay and relocated to the Grška Vela Bay in May 2002. In 2001, the tuna were fed ad libitum one to two times a day (at 11.00 am and 3.00 pm), six times a week. Divers observed the feeding at different depths in order to evaluate the efficiency of the process. In March 2002, the in- tensity of feeding first increased at three to four times a day and afterwards at five to six times a day, seven days a week, from 07.00 am to 07.00 $\mathrm{pm}$, ad libitum. The feeding process was stopped only in case of extremely bad weather conditions.

In cage 2 , the tuna formed weight category (NFTPF) $3.5 \mathrm{~kg}$ and the tuna were fed for 21 months (547 days; from April 2002 till January 2004). During the whole feeding period, in the cages 2, 3 and 4 the intensity of feeding was higher than in cages 1; ad libitum, five to six times a day, seven days a week, from $07.00 \mathrm{am}$ to $07.00 \mathrm{pm}$.

In cage 3, 713 individuals were formed weight category $11 \mathrm{~kg}, 265$ individuals were fromed weight category $17 \mathrm{~kg}$ and 514 individuals were formed weight category $30 \mathrm{~kg}$. The tuna fed for five months (155 days; from August 2003 till January 2004). In cage 4, 5132 individuals were formed weight category $11 \mathrm{~kg}$ and 80 individuals were form weight category $20 \mathrm{~kg}$. The tuna were fed for eight months 240 days; from May 2003 till January 2004. 


\section{Sampling and biochemical analysis}

In total, 40 aquacultured tuna (10 individuals per cage) were collected for biochemical tissue composition analysis, as well as $10 \mathrm{NCTPF}$. The body incisions for muscle sampling are shown in Figure 1.

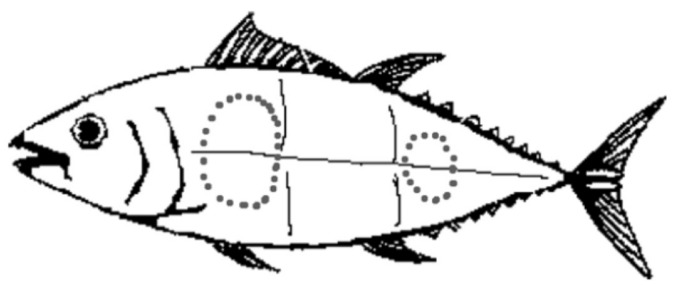

Fig. 1. The position of tuna (T. thynnus) tissue sampling for muscle biochemical composition analysis (after YoshiNori et al., 2007)

The date of sampling, duration of the feeding period, and average body weight of sampled tuna are shown in Table 2. Muscle samples from individual aquaculture tuna and NCTPF tuna were homogenized prior to biochemical analyses of fat, moisture and dry matter, protein and carbohydrate content.

In homogenized samples ( $3 \mathrm{~g})$, fat content was determined following the Association of Official Analytical Chemists (AOAC) Official method 948.15 Fat (Crude) in Seafood - Acid hydrolysis method, 1995 (Hungerford, 1995) modified by RASMUSSEN \& MORRISSEY (2007). The content of moisture and dry matter was determined following the Association of Official Analytical Chemists (AOAC) Official method 950.46 B Convection, Gravity method, 1995 (SODEBERG, 1995). For protein and carbohydrate analyses, tissues were homogenized using the Polytron homogenizer in triple volume of cold $35 \% \mathrm{NaCl}$. Aliquots for protein $(1 \mathrm{ml})$ and carbohydrate analyses (1 $\mathrm{ml})$ were taken from the homogenized sample. Proteins were extracted by adding $0.5 \mathrm{M} \mathrm{NaOH}$ to the aliquot at a $1: 5$ ratio. After $24 \mathrm{~h}$ at $4^{\circ} \mathrm{C}$, the sample was mixed, transferred into a polyethylene test tube and centrifuged at $4000 \mathrm{rpm}$ for 15 minutes at $4^{\circ} \mathrm{C}$. Protein content was determined by the Bradford method using Bovine Serum Albumin (BSA) as standard (Bradford, 1976). Carbohydrate concentration was obtained following SAUCEDO et al. (2002) upon addition of $20 \%$ trichloroacetic acid (Merck) on aliquot at a $1: 1$ ratio.

\section{Statistical analysis}

During the farming period, sea temperature $\left({ }^{\circ} \mathrm{C}\right)$ and oxygen saturation $(\%)$, quantity of given food $(\mathrm{kg})$, the quantities of different types of food $(\mathrm{kg})$ and the mortality (number of individuals and their weight) were measured. The results were encompassed into two groups: the first group included those from the cage 1 and cage 2 , while the second group included those from the cage 3 and cage 4 . This was done because the duration of farming period was markedly different between these two groups. The results were analyzed by software platform IBM SPSS version 10.0: $t$-test and Mann-Whitney test were used $(\mathrm{p}<0.001)$.

Table 2. Muscle sampling for biochemical tissue composition analysis, date, duration of the feeding period, and average body weight of sampled tuna

\begin{tabular}{|c|c|c|c|c|}
\hline & Cage No. & $\begin{array}{c}\text { Duration of farming } \\
\text { (months) }\end{array}$ & Date of sampling & $\begin{array}{c}\text { Average body weight of } \\
\text { sampled tuna (kg) }\end{array}$ \\
\hline $0^{*}$ & - & May 2003 & $25.06 \pm 1.633$ \\
\hline 1 & 21 & January 2003 & $32.18 \pm 2.681$ \\
\hline & 21 & January 2004 & $26.37 \pm 1.759$ \\
\hline & 4 & 8 & January 2004 & $38.43 \pm 2.066$ \\
\hline
\end{tabular}

*0 newly caught tuna prior feeding 


\section{RESULTS}

Table 3a. gives the duration of farming period (months), number of feeding days number of individuals, fish weight $(\mathrm{kg})$, density of the fish in the cages $\left(\mathrm{kg} / \mathrm{m}^{3)}\right.$ at the beginning and at the end of farming period, and monthly mean values, median and min-max for: number of feeding days, the sea temperature $\left({ }^{\circ} \mathrm{C}\right)$, the oxygen saturation (\%). Table $3 \mathrm{~b}$ gives the total quantity of fed food $(\mathrm{kg})$, the quantity of different food types $(\mathrm{kg})$ and mortality (in number of individuals and their weight), as well as the total fed food and percentages of different food types fed to fish, recorded in four cages (DSPF - domestic small pelagic fish).

The fish in the cages 1 and 2 were farmed for 21 months. At the beginning of the farming the total weight of the fish in the cages were 25919 $\mathrm{kg}$ (cage 1) and $23562 \mathrm{~kg}$ (cage 2) while the density of the fish in the cages were $0.73 \mathrm{~kg} / \mathrm{m}^{3}$ (cage 1) and $0.36 \mathrm{~kg} / \mathrm{m}^{3}$ (cage 2). At the end of farming period, the total weight of the fish in the cages were $142404 \mathrm{~kg}$ (cage 1) and $110913 \mathrm{~kg}$ (cage
2) while the density of the fish in the cages were $4.03 \mathrm{~kg} / \mathrm{m}^{3}$ (cage 1) and $1.72 \mathrm{~kg} / \mathrm{m}^{3}$ (cage 2). The total quantity of fed food was: $1933610 \mathrm{~kg}(50 \%$ of herrings, $49 \%$ of DSPF and $1 \%$ of mackerel cage 1 ) and $2,809,644 \mathrm{~kg}$ (33\% of herrings, $38 \%$ of DSPF, $24 \%$ of imported sardine and $5 \%$ of mackerel - cage 2).

The fish in the cages 3 and 4 were farmed for five months (cage 3) and eight months (cage 4) respectively. At the beginning of the farming, the total weight of the fish in the cages were 28079 $\mathrm{kg}$ (cage 1) and $58107 \mathrm{~kg}$ (cage 2), while the density of the fish in the cages were $1.06 \mathrm{~kg} / \mathrm{m}^{3}$ (cage 1) and $1.41 \mathrm{~kg} / \mathrm{m} 3$ (cage 2). At the end of farming period, the total weight of the fish in the cages were 57,494 kg (cage 1) and 137,397 kg (cage 2 ), while the density of the fish in the cages were $2.04 \mathrm{~kg} / \mathrm{m} 3$ (cage 1) and $3.33 \mathrm{~kg} / \mathrm{m} 3$ (cage 2).

The total quantity of feed fed to fish was: $501,427 \mathrm{~kg}$ ( $70 \%$ of herrings, $6.8 \%$ of DSPF $20.2 \%$ of imported sardine - cage 1) and $1,033,472 \mathrm{~kg}$ (33\% of herrings, $38 \%$ of DSPF, $24 \%$ of imported sardine and $5 \%$ of mackerel cage 2).

Table $3 a$. The duration of farming period (months), number of feeding days number of individuals, fish mass (kg), density of the fish in the cages $\left(\mathrm{kg} / \mathrm{m}^{3}\right)$ at the beginning and at the end of farming period, and monthly mean values, median and min-max for: number of feeding days, the sea temperature $\left({ }^{\circ} \mathrm{C}\right)$, the oxygen saturation $(\%)$.

\begin{tabular}{|c|c|c|c|c|c|}
\hline CAGE & 1 & 2 & & 3 & 4 \\
\hline Duration. of farming (months) & 21 & 21 & - & 5 & 8 \\
\hline No. of feeding days & 552 & 547 & - & 155 & 240 \\
\hline No. of indiv. at the beginning & 7183 & 6746 & - & 1502 & 5041 \\
\hline Weight at the beginning $(\mathrm{kg})$ & 25919 & 23562 & - & 28079 & 58107 \\
\hline $\begin{array}{l}\text { Density of the fish at the beginning } \\
\qquad\left(\mathrm{kg} / \mathrm{m}^{3}\right)\end{array}$ & 0.73 & 0.36 & - & 1.06 & 1.41 \\
\hline No. of indiv. at the end & 5314 & 2811 & - & 1449 & 5041 \\
\hline Weight at the end $(\mathrm{kg})$ & 142404 & 111852 & - & 57494 & 137397 \\
\hline Fish density at the end $\left(\mathrm{kg} / \mathrm{m}^{3}\right)$ & 4.03 & 1.72 & - & 2.04 & 3.33 \\
\hline $\begin{array}{l}\text { No of feeding days/month } \\
\operatorname{mv} \pm \text { sd (med;min-max) }\end{array}$ & $\begin{array}{c}26.3 \pm 7.1 \\
(29 ; 2-31)\end{array}$ & $\begin{array}{c}26.2 \pm 5.7 \\
(28 ; 10-31)\end{array}$ & $0.94 *$ & $\begin{array}{c}26 \pm 2.5 \\
(26.5 ; 22-29)\end{array}$ & $\begin{array}{c}27 \pm 3.6 \\
(27 ; 20-31)\end{array}$ \\
\hline $\begin{array}{l}\text { Temperature }\left({ }^{\circ} \mathrm{C}\right) / \text { month } \operatorname{mv} \pm \text { sd } \\
\text { (med;min-max) }\end{array}$ & $\begin{array}{c}18.9 \pm 3,9 \\
(18 ; 13-25)\end{array}$ & $\begin{array}{c}19.0 \pm 4,2 \\
(18 ; 13-25)\end{array}$ & $0.881 *$ & $\begin{array}{c}18.8 \pm 4 \\
(19 ; 13-24)\end{array}$ & $\begin{array}{c}19.8 \pm 3.8 \\
(20 ; 13-24)\end{array}$ \\
\hline $\begin{array}{l}\text { Oxygen saturation \% } \\
\text { mv } \pm \text { sd (med;min-max) }\end{array}$ & $\begin{array}{c}86.3 \pm 5.8 \\
(85 ; 75-99)\end{array}$ & $\begin{array}{c}86.3 \pm 6.3 \\
(87 ; 75-97)\end{array}$ & $0.98^{*}$ & $\begin{array}{c}90 \pm 7.2 \\
(92 ; 77-97)\end{array}$ & $\begin{array}{c}88 \pm 6.9 \\
(91 ; 77-97)\end{array}$ \\
\hline
\end{tabular}

$* t$-test $(\mathrm{p}<0.001)$

(-) no statistical analysis

$m v \pm \mathrm{sd}$ (med;min-max) - Mean Value \pm Standard Deviation (Median; Minimum - Maximum) 
Table $3 \mathrm{~b}$. The total mass of added food ( $\mathrm{kg}$ ), the mass of different types of food ( $\mathrm{kg}$ ) and mortality (in number of individuals and in mass) as well as total added food and percentages of different food types added, recorded for four tuna cages

\begin{tabular}{|c|c|c|c|c|c|}
\hline CAGE & 1 & 2 & & 3 & 4 \\
\hline $\begin{array}{c}\text { TOTAL FOOD /MONTH } \\
\text { (kg) } \\
\text { mv } \pm \text { sd (med;min-max) }\end{array}$ & $\begin{array}{c}88086 \pm 60442 \\
(84949 ; 1572- \\
203492)\end{array}$ & $\begin{array}{c}133794 \pm 68016 \\
(134303 ; 2608- \\
304518)\end{array}$ & $0.04 * *$ & $\begin{array}{l}83571 \pm 19307 \\
(90385 ; 44392- \\
94110)\end{array}$ & $\begin{array}{c}114830 \pm 35619 \\
(123420 ; 59260- \\
159580)\end{array}$ \\
\hline TOTAL FOOD (kg) & 1933610 & 2809644 & - & 501427 & 1033472 \\
\hline $\begin{array}{l}\text { Herring/month }(\mathrm{kg}) \mathrm{mv} \pm \mathrm{sd} \\
\quad(\text { med;min-max) }\end{array}$ & $\begin{array}{c}45028 \pm 72542 \\
(5553 ; \\
0-199435)\end{array}$ & $\begin{array}{l}47169 \pm 56408 \\
(26850 \\
0-162205)\end{array}$ & $0.463 * *$ & $\begin{array}{l}61139 \pm 30351 \\
(63447 ; 2151- \\
93549)\end{array}$ & $\begin{array}{l}61573 \pm 59587 \\
(59260 \\
0-140526)\end{array}$ \\
\hline $\begin{array}{c}\text { Herring/TOTAL FOOD } \\
(\%)\end{array}$ & 50 & 33 & - & 73 & 54 \\
\hline $\begin{array}{l}\mathrm{DSPF} / \mathrm{month}(\mathrm{kg}) \quad \mathrm{mv} \pm \mathrm{sd} \\
\text { (med;min-max) }\end{array}$ & $\begin{array}{l}41840 \pm 37919 \\
(38400 ; 1050- \\
97975)\end{array}$ & $\begin{array}{l}49906 \pm 59802 \\
\quad(20150 \\
0-206821\end{array}$ & $0.882 * *$ & $\begin{array}{c}5674 \pm 5274 \\
(6087 ; 0-11608)\end{array}$ & $\begin{array}{c}7149 \pm 7958 \\
(372 ; 0-19054)\end{array}$ \\
\hline DSPF/TOTAL FOOD (\%) & 49 & 38 & - & 6.8 & 6 \\
\hline $\begin{array}{l}\text { Imported sardine/month } \\
(\mathrm{kg}) \mathrm{mv} \pm \mathrm{sd}(\mathrm{med} ; \mathrm{min}- \\
\max )\end{array}$ & 0 & $\begin{array}{c}30716 \pm 47971 \\
\quad(26023 ; \\
0-146815) \\
\end{array}$ & 0 & $\begin{array}{c}16757 \pm 26705 \\
(0 ; 0-6017)\end{array}$ & $\begin{array}{c}46107 \pm 49396 \\
(47314 ; \\
0-132641) \\
\end{array}$ \\
\hline $\begin{array}{c}\text { Imported sardine/TOTAL } \\
\text { FOOD }(\%)\end{array}$ & 0 & 24 & - & 20.2 & 40 \\
\hline $\begin{array}{l}\text { Mackerel/month (kg) } \\
\text { mv } \pm \text { sd (med;min-max) }\end{array}$ & $\begin{array}{l}1217,6 \pm 4318 \\
(0 ; 0-16764)\end{array}$ & $\begin{array}{l}6003 \pm 16009 \\
(0 ; 0-67619)\end{array}$ & $0.194 * *$ & 0 & 0 \\
\hline $\begin{array}{c}\text { Mackerel/ TOTAL FOOD } \\
(\%)\end{array}$ & 1 & 5 & - & 0 & 0 \\
\hline $\begin{array}{l}\text { Food/individual*month } \\
\text { (kg) } \\
\mathrm{mv} \pm \mathrm{sd} \text { (med;min-max) }\end{array}$ & $\begin{array}{c}17 \pm 10,5 \\
(15,8 ; 0,03- \\
38,2)\end{array}$ & $\begin{array}{c}31,7 \pm 14,9 \\
(31,5 ; 3,9-63,4)\end{array}$ & $0.001 * *$ & $\begin{array}{c}57 \pm 13 \\
(61 ; 31-64,5)\end{array}$ & $\begin{array}{c}22,5 \pm 7 \\
(24,5 ; 12-32)\end{array}$ \\
\hline $\begin{array}{c}\text { Mortality/month } \\
\text { (no of indiv.) } \\
\text { mv } \pm \text { sd (med;min-max) }\end{array}$ & $\begin{array}{c}89 \pm 201 \\
(5 ; 0-785)\end{array}$ & $\begin{array}{c}134 \pm 344 \\
(11 ; 0-1549)\end{array}$ & $0.226^{* *}$ & $\begin{array}{c}8,8 \pm 9,6 \\
(5,5 ; 0-21)\end{array}$ & $\begin{array}{c}17 \pm 17 \\
(8 ; 0-48)\end{array}$ \\
\hline $\begin{array}{l}\text { Mortality/month (kg) } \\
\text { mv } \pm \text { sd (med;min-max) }\end{array}$ & $\begin{array}{c}380 \pm 773 \\
(68 ; 0-2964)\end{array}$ & $\begin{array}{c}919 \pm 1803 \\
(151 ; 0-6695)\end{array}$ & $0.125^{* *}$ & $\begin{array}{c}175 \pm 181 \\
(111 ; 0-413)\end{array}$ & $\begin{array}{c}226 \pm 230 \\
(163 ; 0-772)\end{array}$ \\
\hline $\begin{array}{l}\text { **Mann-Whitney test }(\mathrm{p}<0.0 \\
\text { (-) no statistical analysis } \\
D S P F-\text { domestic small pelą } \\
m v \pm \mathrm{Sd} \text { (med;min-max) - Mea }\end{array}$ & sh; & & & & \\
\hline
\end{tabular}

Table 3. indicates statistically significant difference only for feed fed per individual per month $(\mathrm{p}<0.001)$ for the first group of cages (cages 1 and 2), as well as for feed fed per individual, per month, and for total feed fed per months for the second group of cages (cages 3 and 4).

Table 4. indicates values of fat, moisture, dry matter, protein and carbohydrate content in tuna muscles farmed in four different cages and wildcaught tuna muscles. The table 4 . shows that the highest values of moisture as well as the lowest values of dry matter and fat was measured in the sample 0 (newly caught tuna prior feeding), while the highest values of dry matter and fat, as well as the lowest values of moisture, were measured in sample 3 (the fish from cage 2). In June and July 2002, the fish in the cage 2 had high mortality because of the skin damage that some fish obtained due to bad weather conditions during the transport. The fish that were transported in June 2002 did not have a period of adaptation to the captivity and the fish were fed intensively immediately after transport, while in other cages feeding process was extensive in the beginning and the quantity of feed progressively increased. 
MiLETIĆ et. al.: The influence of feeding on muscle tissues composition in cage reared bluefin tuna ...

Table 4. The values of fat, moisture, dry matter, protein and carbohydrate content in tuna muscles

\begin{tabular}{|c|c|c|c|c|c|}
\hline Cage No. & Fat (\%) & Dry matter (\%) & Moisture (\%) & Proteins (\%) & Carbohydrates (\%) \\
\hline $0^{*}$ & 0.90 & 19.64 & 80.36 & 13.77 & 0.31 \\
\hline 1. & 20.62 & 44.74 & 55.26 & 18.60 & 0.66 \\
\hline 2. & 42.50 & 60.05 & 39.95 & 16.00 & 0.37 \\
\hline 3. & 20.97 & 45.36 & 54.64 & 15.09 & 0.83 \\
\hline 4. & 20.57 & 50.30 & 49.70 & 20.58 & 0.57 \\
\hline
\end{tabular}

*0 newly caught tuna prior feeding

\section{DISCUSSION}

In wild-caught tuna, stored fat was found to be less than $1 \%$ of the total body weight, compared to over $20 \%$ of the total body weight in aquacultured tuna. Continuous high-energy diet and lower activity may cause higher fat content in cultured fish (NAKAMURA et al., 2007). The level of fat in the flesh partly depends upon the dietary fat levels (MOURENTE \& TOCHER, 2009), the fish's capacity to digest proteins and feed conversion ratio (GRAHAM 1975). The composition of fats (except for cage $2 ; 42.50 \%$ ) were lower, compared to previous studies in the bluefin tuna: $23.0 \%$ (NAKAMURA et al., 2007), 27.5\% (KAGAWA, 2001), and from $27.30 \%$ to $28.96 \%$ (MISLOV JELAVIC et. al., 2012). The highest fat content found in cage 2 (twice the value found in cage 1) could have different reasons. Firstly, the density of captive fish was lower $(6,743$ of individuals) compared to cage 1 (7,183 individuals), although fish were farmed for the same period of time (21 months). Also, fish from cage 2 had a lower initial biomass (on average $26.37 \mathrm{~kg}$ ) compared to fish from cage 1 (on average $32.18 \mathrm{~kg}$ ). Additionally, different hydrographic conditions (temperature and oxygen) might have attributed to such differences, since farming in cage 2 started a year later than in cage 1. According to GIMENEZ-CASALDUERO \& SANCHEZ-JEREZ (2006) fat content is tightly related to the fish metabolism, therefore depends on the water temperature (higher in temperate water compared to tropical water), animal size (higher in large adults than in juveniles) and sexual maturity (higher before spawning than after spawning).

Interestingly, tuna kept in cage 1 . that were farmed for two consecutive cycles (21 months) did not differ in fat, dry matter and moisture content compared to tuna farmed for five months. These results demonstrate that high fat content can be achieved already after five months of intensive feeding. The potential benefits of high fat diets such as rapid growth, may have to be balanced with potential deleterious effects such as reduced product quality and consumer acceptance (MOURENTE \& TOCHER, 2009), although in tuna this is not the case. According to DOSDAT (2015) during the aquaculture process water is the vehicle for both feed and waste. Metabolic wastes and feed (uneaten and undigested feed, indigestible compound originating from food and excreta) result in water quality degradation, therefore water quality is an important variable to consider when planning feeding schemes in tuna aquaculture.

The observed moisture content in this study corresponds to the proximate composition of moisture in the ventral muscle of bluefin tuna (51.4\%) according to the Standard Tables of Food Composition in Japan (KAGAWA, 2001). In Atlantic northern bluefin tuna, high body fat content and low water content usually indicates that the fish has stored enough energy in its muscle fat reserves for migrations (CLAY, 1988). Farmed fish showed higher fat and lower moisture content than wild specimens, due to a high dietary fat level in the feed and reduced activity (PERIAGO et al., 2005). SIDWELL et al. (1974) found that bluefin tuna had fat content $3.9 \%$ and moisture content $70.4 \%$ due to their high protein content. For the tuna in this study the lowest fat percentage was $20.57 \%$ (Cage 4) while the highest moisture content was $55.26 \%$ (Cage 1) (Table 4.) 
Higher content of proteins was also found in aquacultured tuna compared to wild-caught tuna, while there were no differences in protein content in tuna reared for one or two cycles. According to MOURENTE \& TOCHER (2009), protein composition was observed to be less variable than fat composition, although the average composition of protein observed herein has been generally lower compared to other studies; $20.1 \%$ (KAGAWA, 2001), 21.09\% (TOPIC POPOVIC et al., 2012) and 25.4\% (BIMOL et al., 2010). Fish muscles that contain small amounts of protein tend to lose considerable water upon cooking, which negatively affects the texture of the meat (OKLAND et al., 2005), making the protein content an important element in considering the quality and texture of the fish muscle (TOPIC POPOVIC et al., 2012). There are no differences in carbohydrates content between tuna reared for one and two cycles, as well as between farmed and NCTPF tuna. Carbohydrate originates from body glycogen which burns and regenerates is synthesized and degraded quickly, indicating that glycogen it is a less optimal parameter of muscle quality in farmed fish.

\section{REFERENCES}

BIMOL, C. R., Y. MIYAKE, M. ANDO, K.I. KAWASAKI, \& Y. TSUKAMASA. 2010. Proximate and Fatty Acid Compositions in Different Flesh Cuts of Cultured, Cultured Fasted, and Wild Pacific Bluefin Tuna (Thunnus orientalis). J. Aquat. Food Prod. T., 19 (3-4): 284-297.

BRADFORD, M.M. 1976. A rapid and sensitive for the quantitation of microgram quantitites of protein utilizing the principle of protein-dye binding. Anal. Biochem., 72: 248-254.

CLAY, D. 1988. Fat, water, protein and ash of bluefin tuna collected in the Gulf of St. Lawrence. ICCAT Coll. Vol. Sci. Pap., 28: 196-202.

DOSDAT, A. 2015. Fisheries and aquaculture - Vol. IV - Environmental Impact of Aquaculture. https://www.researchgate.net/publication/268175875_ENVIRONMENTAL_IMPACT_OF_AQŪACULTURE [accessed Jul $222018]$.

FARNDALE, B. M., J. G. BELL, M. P. BRUCE, N. R. BROMAGE, F. OYEN, S. ZANUY \& J. R. SARGENT. 1999. Dietary lipid composition affects blood leucocyte fatty acid compositions and plasma eicosanoid concentrations in European sea bass (Dicentrarchus labrax). Aquacult., 179: 335-350.

FLOS, R., L. REIG, J. OCA \& M. GINOVART. 2002. Influence of marketing and different land-based systems on gilthead sea bream (Sparus aurata) quality. Aquacult. Int., 10: 189-206.

GIMENEZ-CASALDUERO, F. \& P. SANCHEZ-JEREZ. 2006. Fattening rate of bluefin tuna Thunnus thynnus in two Mediterranean fish farms. Cybium, 30(1): 51-56.
GLENCROSS, B. D., M. BOOTH \& G. L. ALLAN. 2007. A feed is only as good as its ingredients - a review of ingredient evaluation strategies for aquaculture feeds. Aquacult. Nutr., 13: 17-34.

GRAHAM, J.B. 1975. Heat exchange in the yellowfin tuna Thunnus albacore and skipjack tuna Katsuwonus pelamis and the adaptive significance of elevated body temperatures in scombrid fishes. Fish. Bull., 73: 219-229.

GRIGORAKIS, K., M. N., ALEXIS, K. D. A. TAYLOR \& M. HOLE. 2002. Comparison of wild and cultured gilthead sea bream (Sparus aurata), composition, appearance and seasonal variations. Int. J. Food. Sci. Technol., 37: 477-484.

HAARD, N. F. 1992. Control of chemical composition and food quality attributes of cultured fish. Food Res. Int., 25: 289-307.

HEMRE, G. I. \& K. SANDNES. 1999. Effect of dietary lipid level on muscle composition in Atlantic salmon Salmo salar. Aquacult. Nutr., 5: 9-16.

HUNGERFORD, J. M. 1995. Fish and other marine products. In: Official methods of analysis of AOAC international. Editors: P. Cunniff, Arlington, USA, pp. 130.

KAGAWA, Y. 2001. Standard Tables of Food Composition in Japan. Kagawa Nutrition University Press, Tokyo, Japan.

KATAVIC, I., V. TIČINA \& V. FRANIČEVIĆ. 2003. Rearing of small Bluefin tunas (Thunnus thynnus L.) in the Adriatic Sea-preliminary study. Cahiers Options Mediterraneennes, 60: 95-99.

MISLOV JELAVIC K., K. STEPANOWSKA, L. 
GRUBIŠIĆ, T. ŠEGVIĆ BUBIĆ \& I. KATAVIĆ. 2012. Reduced feeding effects to the blood and muscle chemistry of farmed juvenile bluefin tuna in the Adriatic Sea. Aquacult. Res., 43: 317-320.

MLADINEO, I., I. MILETIC \& I. BOCINA. 2006. Photobacterium damselae subsp. piscicida outbreak in cage-reared Atlantic bluefin tuna (Thunnus thynnus). J. Aquat. Anim. Health, 18: $51-54$.

MOURENTE, G. \& R. TOCHER. 2009. Tuna nutrition and Feeds: Current Status and Future Perspectives. Rev. Fish. Sci., 17 (3): 374-391. NAKAMURA, Y.N., M. ANDO, M. SEOKA, K.I. KAWASAKI \& Y. TSUKAMASA. 2007. Changes of proximate and fatty acid compositions of the dorsal and ventral ordinary muscles of the full-cycle cultured Pacific bluefin tuna Thunnus orientalis with the growth. Food Chem., 103: 234-241.

OKLAND, H.M.W., I.S. STOKNES, J.F. REMME M. KJERSTAD \& M. SYNNES. 2005. Proximate composition, fatty acid and lipid class composition of the muscle from deep-sea teleosts and elasmobranchs. Comp. Biochem. Physiol., B: Comp. Biochem., 140: 437-443.

ORBAN, E., T. NEVIGATO, G. DI-LENA, I. CASINI \& A. MARZETTI. 2003. Differentiation in the lipid quality of wild and cultured sea bass ( $\mathrm{Di}$ centrarchus labrax) and gilthead sea bream (Sparus aurata). J. Food Sci., 68: 128-132.

PERIAGO, M.J., M.D. AYALA, O. LOPEZ-ALBORS, I. ABDEL, C. MARTINEZ, A. GARCIA-ALCAZAR, G. ROS \& F. GIL. 2005. Muscle cellularity and flesh quality of wild and farmed sea bass, Dicentrarchus labrax L. Aquaculture, 249: 175-188.

RASMUSSEN, R. S. 2001. Quality of cultured salmonids with emphasis on proximate composition, yield and sensory characteristics. Aquacult. Res. 32, 767-786.

RASMUSSEN, R. S. \& M. T. MORRISSEY. 2007. Effects of canning on total mercury, protein, lipid, and moisture content in troll-caught albacore tuna (Thunnus alalunga). Food Chem., 101 (3): 1130-1135.
SAUCEDO, P., I. RACOTTA, H. VILlAREA, \& M. MONTEFORTE. 2002. Seasonal changes in the histological and biochemical profile of the gonad, digestive gland, and muscle of the calafia mother-of-the-pearl oyster, Pinctada mazatlantica (Hanley, 1856) associated with gametogenesis. J. Shellfish Res., 21, 127-135. SIDWELL, V.D., P.R. FONCANNON, N.S. MOORE \& J.C., BONNET. 1974. Composition of the edible portion of raw crustaceans, finfish, and mollusks. 1. Protein, Fat, Moisture, Ash, Carbohydrate, Energy Value, and Cholesterol. Mar. Fish. Rev., 36, 21-35.

SKOG, T. E., K. HYLLAND, B. E. TORSTENSEN \& M. H. G. BERNTSSEN. 2003. Salmon farming affects the fatty acid composition and taste of wild saithe Pollachius virens L. Aquacult. Res., 34: 999-1007.

SODERBERG, D. L. 1995. Meat and meat products. In: Official methods of analysis of AOAC international. Eds: P. Cunniff, Arlington, USA, pp. 1-23.

SORIGUER, F., S. SERNA, E. VALVERDE, J. HERNANDO, A. MARTIN-REYES, M. SORIGUER, A. PAREJA, F. TINAHONES \& I. ESTEVA. 1997. Lipid, protein and calorie content of different Atlantic and Mediterranean fish, shellfish, and molluscs commonly eaten in the south of Spain. Eur. J. Epidemiol., 13: 451-463.

TOMIĆ, M., Z. LUCEVIĆ, T. TOMLJANOVIĆ, D. MATULIĆ. 2017. Wild-caught versus farmed fish - consumer perception. Croatian Journal of Fisheries, 75: 41-50.

TOPIĆ POPOVIĆ, N., L. KOZACINSKI, I. STRUNJAKPEROVIĆ, R. COZ-RAKOVAC, M. JADAN, Z. CVRTILA-FLECK \& J. BARIŠIĆ. 2012. Fatty acid and proximate composition of bluefin tuna (Thunnus thynnus) muscle with regard to plasma lipids. Aquacult. Res., 43: 722-729.

YOSHI-NORI, N., A. MASASHI, S. MANABU, K. KENICHI \& T. YASUYUKI. 2007. Changes of proximate and fatty acid compositions of the dorsal and ventral ordinary muscles of the full-cycle cultured Pacific bluefin tuna Thunnus orientalis with the growth. Food Chem., 103: 234-241. 


\title{
Utjecaj hranidbe na sastav mišićnog tkiva plavoperajne tune (Thunnus thynnus) uzgajane u kavezima
}

\author{
Ivana MILETIĆ, Ivona MLADINEO, Stjepan ORHANOVIĆ, \\ Maja PAVELA-VRANČIĆ, Merica SLIŠKOVIĆ i Gorana JELIĆ MRČELIĆ
}

\begin{abstract}
SAŽETAK
Kavezni uzgoj tune uhvaćene u divljini, tijekom razdoblja dužeg od jedne godine, sve dok tuna ne dobije znatno na težini, jedan je od najznačajnijih akvakulturnih aktivnost u Hrvatskoj. Cilj ovog rada je odrediti utjecaj intenziteta i duljine ishrane na biokemijski sastav bijelog mišićnog tkiva (ukupni sadržaj masti, vode, suhe tvari, ugljikohidrata i proteina) tek ulovljene tune (Thunnus thynnus) prije tovljenja, u odnosu na tunu uzgajanu u kavezima kružnog oblika između 2001. i 2004. u uvali Vela Grška, koja se nalazi na južnoj obali otoka Brača u hrvatskom dijelu Jadranskog mora (LAT $43^{\circ} 17^{\prime} 40,6984^{\prime}$ N, LONG $016^{\circ} 28^{\prime} 58,4315^{\prime}$ 'E (WGS84)). Tuna uzgajana u sva četiri kaveza hranjena je domaćom malom plavom ribom ili mješavinom haringe iz Sjevernog mora (Clupea harengus) i srdele (Sardina pilchardus), i to tijekom pet mjeseci (kavez 3), osam mjeseci (kavez 4) odnosno 21 mjesec (kavezi 1 i 2). Niski udjeli vode i visoki udjeli suhe tvari, uključujući masti, zabilježeni su u mišićnom tkivu uzgajane tune u odnosu na divlju tunu. U mišićnom tkivu kavezno uzgajane tune zabilježeno je 55.26\% vode u kavezu 1, 39.95\% u kavezu 2, 54.64\% u kavezu 3 i 49.70\% u kavezu 4, što su značajno niže vrijednosti od vrijednosti izmjerenih za divlju tunu (80.36\%). Udio suhe tvari u mišićnom tkivu uzgajane tovljene tune značajno se razlikovao od udjela suhe tvari nađene u mišićnom tkivu divlje tune (19.64\%), ali u mišićnom tkivu tuna uzgajanih u različitim kavezima (44.74\% u kavezu 1, 60.05\% u kavezu 2, 45.36\% u kavezu 3 i 50.30\% u kavezu 4).

Ukupne masti u mišićnom tkivu čine manje od 1\% ukupne težine tijela divlje tune, dok su te vrijednosti u tovljenih tuna: $20.62 \%$ u kavezu 1, 42.50\% u kavezu 2, 20.97\% u kavezu 3 i 20.57\% u kavezu 4. Ovi rezultati upućuju na to da se visok sadržaj masti može postići već nakon pet mjeseci intenzivnog tovljenja tune. Visoke vrijednosti udjela proteina nađene su u mišićnom tkivu uzgajanih tuna (18.60\% u kavezu 1, 16.00\% u kavezu 2, 15.09\% u kavezu 3 i 20.58\% u kavezu 4) u usporedbi s mišićnim tkivom divlje tune (13.77\%).

Udio ugljikohidrata u mišićnom tkivu tuna nije se značajno razlikovao između tuna uzgajanih u različitim kavezima ( $0.83 \%$ u kavezu 1, 0.57\% u kavezu $2.066 \%$ u kavezu 3 i 0.37 u kavezu 4), kao ni u usporedbi s mišićnim tkivom divljih tuna $(0.31 \%)$. Kako ugljikohidrati potječu iz glikogena koji se brzo sintetizira i razgrađuje, sadržaj glikogena u mišićnom tkivu tune, manje je pogodan parametar za ocjenu kvalitete mišićnog tkiva uzgajane ribe.
\end{abstract}

Ključne riječi: plavoperajna tuna, sastav mišićnog tkiva, kavezni uzgoj, uvala Vela Grška 